
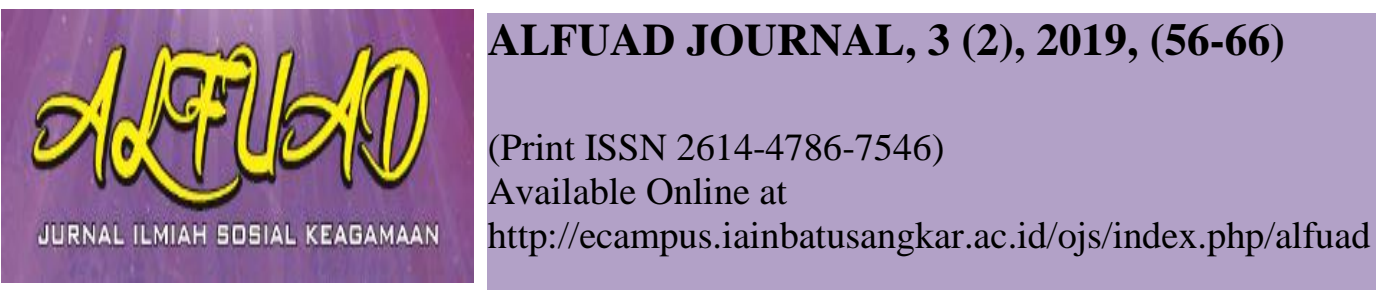

\title{
IJTIHAD POLITIK NU NEGARA PANCASILA ADALAH NEGARA ISLAM
}

\section{Fajar Syarif}

Institut Ilmu Al-Qur'an (IIQ) Jakarta

Email: fajarsyarif@gmail.com

\begin{abstract}
The debate over the relationship between religion and the state reappeared when the New Order regime was at its peak of power, the 1980s. This has a fundamental need to strengthen the Unitary State of the Republic of Indonesia (NKRI) and establish Pancasila as the only state ideology and the only principle for religious and social organizations. This need certainly created an extraordinary paradigmatic controversy among all components of the nation, especially Muslims: between following the political will of the New Order or remaining a supporter of the establishment of an "Islamic state", not a Pancasila state. This is a big dilemma for the Indonesian people which in reality consists of thousands of islands, hundreds of ethnicities and languages, and dozens of religions, while the majority of the population is Muslim where the idea of establishing an 'Islamic state' has not vanished from the ideals of a number of Islamic organizations or groups.
\end{abstract}

Keywords: Religion, Nation, Islam, $N U$

\section{PENDAHULUAN}

Meski Pancasila telah ditetapkan sebagai satu-satunya asas dalam UU Nomor 8 Tahun 1985 tentang Organisasi Kemasyarakatan, tetapi begitu rezim Orde Baru tumbang dari kekuasaannya, gagasan pendirian "negara Islam" muncul kembali. Ini terjadi beberapa bulan saja dari tanggal kejatuhan rezim Orde Baru, 21 Mei 1998. Rezim Orde Baru tumbang ditandai dengan pengunduran diri Presiden Soeharto atas desakan demontrasi ribuan mahasiswa selama berhari-hari menyusul terjadinya
Kerusuhan Mei 1998 dan pendudukan gedung DPR/MPR oleh ribuan mahasiswa.

Dalam derasnya arus demokrasi paska kejatuhan Orde Baru, gerakan islamis kembali memainkan peran politik identitas. Tidak saja secara leluasa mendirikan partai politik dan organisasi massa berasaskan (berideologikan) Islam (Azra, 2006), sesuatu yang dilarang pada zaman Orde Baru. Dalam UU Nomor 8 Tahun 1985 ditetapkan bahwa Pancasila adalah satu-satunya asas bagi semua organisasi kemasyarakatan dan politik. Dengan demikian, semua organisasi tidak dimungkinkan lagi berasaskan dan 
berideologikan selain Pancasila, tetapi juga secara terang-terangan menyuarakan aspirasi lamanya memasukkan kembali tujuh kata Piagam Jakarta ke dalam UUD 1945 (Ma'arif, 1985; Nasution, 1992); Anshari, 1997). Desakan kalimat “dengan kewajiban menjalankan syari'at Islam bagi pemelukpemeluknya" untuk menggantikan Pasal 29 UUD 1945 disampaikan pada Sidang Umum MPR 1999, Sidang Tahunan MPR 2000, dan Sidang Tahunan MPR 2001, dan Sidang Tahunan MPR 2002 dalam paket Amandemen UUD 1945 (Lindsey, 2002: 246, 250, 269-271; Hosen, 2007: 188-215; Basalim, 2000).

Di Parlemen, ide memasukkan 'tujuh kata' tersebut diusung Fraksi Partai Persatuan Pembangunan dan Partai Bulan Bintang. Sementara kelompok seperti Dewan Dakwah Islamiyah Indonesia, Hizbut Tahrir, Majelis Mujahidin, Front Pembela Islam, dan Kongres Umat Islam (Basalim, 2002), menyokong dengan aksi-aksi di luar Parlemen, seperti turun jalan, mimbarmimbar khotbah, buku-buku, spanduk, hingga selebaran Jumat. Aspirasi mereka menjadi bahan perbincangan nasional, baik dalam gedung DPR/MPR maupun dalam sidang publik.

Meskipun gagal pada Sidang Tahunan MPR 2000 (Basalim, 2002: 259260), mencermati perjuangan mereka yang terus menerus dengan berbagai strategi, aspirasi mendirikan negara Islam (Rais,
2002: xv) dan penegakan syari'at Islam tampaknya tetap menjadi agenda yang terus diperjuangkan dengan memanfaatkan segala jenis peluang, termasuk demokrasi. Shalahuddin Wahid menjelaskan bahwa relasi agama dan negara dalam kaitan dengan pelaksanaan Syari'at Islam oleh negara dapat dibedakan dalam lima tingkatan penerapan. Pertama, masalah hukum kekeluargaan, seperti perkawinan, perceraian, dan kewarisan. Kedua, urusan ekonomi dan keuangan, seperti perbankan Islam dan zakat. Ketiga, praktik ritual keagamaan, seperti mengenakan jilbab dan sanksi bagi yang tidak puasa. Keempat, penerapan hukum pidana Islam, terutama berkaitan dengan jenis sanksi yang dijatuhkan pada pelanggar. Kelima, penggunaan Islam sebagai dasar negara dan sistem kenegaraan. (KOMPAS, 7 April 2002).

\section{HASIL DAN PEMBAHASAN}

Seperti telah disinggung di atas bahwa pada tanggal 22 Oktober 1945, Rais Akbar KH. M. Hasyim Asy'ari mengeluarkan fatwa Resolusi Djihad yang mewajibkan setiap orang (fardlu 'ain) dalam radius $94 \mathrm{~km}$ untuk melakukan jihad fi sabilillah melawan tentara sekutu dan NICA. Tentara Sekutu saat itu mendarat lagi di Tanah Air untuk menjajah setelah kemerdekaan RI. Fatwa ini kemudian dikukuhkan sebagai Keputusan Muktamar NU ke-16 di Purwokerto, 26-29 Maret 1946 
(Masyhuri, 1997: 197). Keputusan Muktamar itu secara lengkap berbunyi pertama Berperang menolak dan melawan pendjadjah itoe Fardloe 'ain (jang harus dikerdjakan oleh tiap-tiap orang-orang Islam, laki-laki, perempoean, anak-anak, bersendjata atau tidak (bagi orang jang berada dalam djarak lingkaran $94 \mathrm{Km}$ dari tempat masoek dan kedoedoekan moesoeh). Kedua Bagi orang-orang jadi berada diloear djarak lingkaran tadi, kewadjiban itu djadi fardloe kifayah (jang tjoekoep, kalau dikerdjakan sebagian sadja). Ketiga Apa bila kekoeatan dalam No. 1 beloem dapat mengalahkan moesoeh, maka orang-orang jang berada diloear djarak lingkaran $94 \mathrm{Km}$. wadjib berperang djoega membantoe No. 1 sehingga moesoeh kalah. Keempat Kaki tangan moesoeh adalah pemetjah kegoelatan teqat dan kehendak ra'jat dan haroes dibinasakan, menoeroet hoekoem Islam saba Chadist, riwajat Moeslim.

Keputusan Muktamar ini merupakan dukungan politik keagamaan NU yang sangat berani dan mampu mempengaruhi semangat rakyat untuk mempertahankan bentuk negara Indonesia yang baru diproklamasikan. Resolusi Jihad inilah tampaknya yang menyulut semangat arekarek Jawa Timur dan Bung Tomo melawan tentara sekutu dan NICA di Surabaya pada 10 November 1945-yang kemudian ditetapkan sebagai Hari Pahlawan.
Kerangka berpikir NU yang sangat nasionalis dalam membela negara Indonesia bahkan ditemukan jauh sebelum kemerdekaan. Dalam Muktamar ke-11 di Banjarmasin, 9 Juni 1935, NU telah memberikan status hukum negara Indonesia yang saat itu masih dikuasai oleh Pemerintah Penjajah Belanda dengan "Darul Islam" (negeri Islam). Argumentasinya adalah meskipun saat itu Indonesia masih dikuasai oleh penjajahan Belanda, tetapi dalam sejarahnya Nusantara pernah dikuasai sepenuhnya oleh orang Islam dan orang Islam dapat secara bebas menjalankan syari'at keagamaannya. Dalam Muktamar ke-11 itu muncul pertanyaan:

“Apakah nama negara kita menurut syara' agama Islam?” Keputusan Muktamar menyatakan: "Sesungguhnya negara kita Indonesia dinamakan negara Islam karena telah pernah dikuasai sepenuhnya oleh orang Islam. Walaupun pernah direbut oleh kaum penjajah kafir, tetapi nama negara Islam tetap selamanya." Argumen fiqhnya diambilkan dari Kitab Bughyatul Mustarsyidin, pada Bab Hudnah wal Imâmah. Dalam teks kitab itu disebutkan “..... fa 'ulima anna ardla batawiy (Jakarta) bal wa ghâlib ardli jâwâ dâru islâmin li istîlâ'i al-muslimîna 'alayhâ qabl al-kuffâr (Masyhuri, 1997: 138).

Para ulama berbeda pendapat dalam menentukan identitas suatu negara untuk bisa dikategorikan sebagai Darul Islam. 
Sebagian ulama melihat hal itu dari sudut hukum yang berlaku di negara tersebut. Ada pula yang melihat dari sisi keamanan warganya dalam menjalankan Syari'at Islam. Sementara ada ulama lain yang melihat dari sisi pemegang kekuasaan negara tersebut.

Imam Abu Yusuf (w. 182 H.), tokoh besar madzhab Hanafiyah, berpendapat bahwa suatu negara dapat disebut sebagai Darul Islam apabila di dalamnya telah berlaku hukum Islam, meskipun mayoritas warganya bukan Muslim. Sementara Darul Charb (lawan Darul Islam) menurutnya adalah negara yang tidak memberlakukan hukum Islam, meskipun sebagian besar penduduknya beragama Islam (Sarkhasi, 144).

Al-Kisani (w. 587 H.), juga dari madzhab Hanafiyyah, memperkuat pendapat Imam Abu Yusuf. Menurutnya, Darul Charb bisa menjadi Darul Islam apabila negara tersebut memberlakukan hukum Islam. Dalam pemikiran modern, pandangan demikian juga dianut oleh Sayyid Quthb (w. 1387 H.). Tokoh gerakan Islam al-Ikhwanul Muslimun ini memandang bahwa negara yang menerapkan hukum Islam dapat disebut sebagai Darul Islam, tanpa mensyaratkan penduduknya harus Muslim atau bercampur baur dengan ahluzd zdimmi.(Qutb, t.th: 874).

Imam ar-Rafi'i (w. 623 H.), salah seorang tokoh fikih madzhab Syafi'i, menjadikan alat ukur untuk menentukan apakah sebuah negara disebut Darul Islam atau Darul Charb dengan mempertimbangkan agama para pemegang kekuasaan dalam negara tersebut. Suatu negara dipandang sebagai Darul Islum apabila dipimpin oleh seorang Muslim, demikian sebaliknya.

Sedangkan Imam Abu Hanifah (80150 H.) membedakan Darul Islam dan Darul Charb berdasarkan rasa aman yang dinikmati oleh penduduknya yang beragama Islam. Apabila umat Islam merasa aman dalam menjalankan aktivitas keagamaanya, maka negara tersebut termasuk kategori Darul Islam. Sebaliknya, apabila tidak ada rasa aman untuk umat Islam, maka negara itu masuk dalam kategori Darul Charb (alZuhaili, t.th: 56).

Sementara Ibnul Qayyim al-Jawziyah (w. 751 H.) berpendapat bahwa Darul Islam adalah negara yang wilayahnya didiami oleh (mayoritas) umat Islam dan hukum yang berlaku di negara tersebut adalah hukum Islam. Apabila kedua unsur ini tidak terpenuhi, maka negara itu bukan Darul Islam (Al-Jauziyah, t.th: 226).

Apabila berbagai tolok ukur ini digabungkan secara kumulatif, maka Darul Islam adalah negara yang dihuni oleh mayoritas umat Islam, dipimpin oleh orang Islam, dan di dalamnya diberlakukan Syari'at Islam secara aman. Itulah sebabnya Javid Iqbal dalam tulisannya, The Concept of State in Islam, menyatakan bahwa Darul Islam adalah negara yang pemerintahannya 
dipegang oleh umat Islam, mayoritas penduduknya beragama Islam, dan undangundangnya menggunakan hukum Islam (Ahmad, 1986: 38).

Sebaliknya, tolok ukur minimal "negara Islam" adalah bisa dilaksanakannya Syari'at Islam dalam suatu negara dengan aman, tanpa mempertimbangkan mayoritas penduduknya beragama Islam dan pemimpin negaranya beragama Islam atau tidak. Artinya, keamanan menjalankan Syari'at Islam tidak mesti berhubungan dengan agama yang dianut oleh kepala negara mayoritas agama penduduknya. Sehingga, Syari'at Islam bisa saja dilaksanakan di suatu wilayah yang dipimpin oleh kepala negara yang non-Muslim. Karenanya, suatu wilayah bisa disebut Darul Islam meskipun tidak dipimpin oleh orang Islam sepanjang Syari'at Islam bisa dijalankan dengan aman.

Tolok ukur ini digunakan oleh NU dalam muktamarnya di Banjarmasin pada tahun 1935. Keputusan NU ini sejalan dengan pandangan yang berkembang di dalam madzhab Syafi'iyyah, yakni pendapat Imam Nawawi. Menurut Imam Nawawi, Darul Islam yang telah dikuasai oleh nonMuslim tetap dipandang sebagai Darul Islam apabila umat Islam masih tetap bermukim di dalamnya. Artinya, Darul Islam yang kemudian dikuasai oleh non-Muslim tidak berubah status menjadi Darul Charb apabila orang Islam yang menetap di dalamnya tidak dihalangi untuk melaksanakan syari'at agamanya. Akan tetapi, jika penguasa nonMuslim tersebut menghalangi umat Islam untuk melaksanakan ajaran agamanya, maka status Darul Islam berubah menjadi Darul Charb (al-Anshari, t.th: 454)

Dengan logika ini, mempertahankan keberadaan Indonesia dan mengisinya dengan persatuan-kesatuan, kedamaian, kerukunan, dan lebih-lebih keadilankemanusiaan menjadi sangat penting bagi Nahdlatul Ulama.

Ini paralel dengan paradigma berpikir yang digunakan KH. A. Wahid Hasyim, wakil NU, pada masa-masa genting perumusan dasar negara Indonesia yang akan diproklamasikan pada Agustus 1945. Meskipun KH. A. Wahid Hasyim ikut menyusun Piagam Jakarta tanggal 22 Juni 1945, namun demi menjaga keutuhan bangsa akibat keberatan-keberatan penduduk dari Indonesia Timur yang tidak beragama Islam, pada tanggal 18 Agustus 1945 KH. Wahid Hasyim ikut menyetujui dihapuskan kalimat “dengan kewajiban menjalankan sjari'at Islam bagi pemeluk-pemeluknya" dari Mukaddimah UUD. Sebagai gantinya, KH. Wahid Hasyim mengusulkan agar diganti dengan rumusan "Ketuhanan Yang Maha Esa." Kata "Esa" menggarisbawahi keesaan Tuhan (tauhid) yang tidak terdapat pada agama lain (Feillard, 1999: 39).

Atas nalar ini pula, NU secara tegas menolak gagasan dan kehadiran Negara Islam Indonesia (NII) yang didirikan oleh 
Kartosuwiryo di Jawa Barat (7 Agustus 1949), Kahar Muzakar di Sulawesi Selatan (1952), Daud Beureuh di Aceh (1953), dan Ibnu Hajar di Kalimantan Selatan (1953) (Feillard, 1999: 7). Ulama NU memberikan keputusan fikih kepada Kartosuwiryo sebagai pelaku bughat (pemberontak kepada negara yang sah) akibat pemikiran dan gerakannya itu.

Pengakuan NU terhadap pemerintahan yang sah dilakukannya pada Konferensi Nasional Alim Ulama NU di Cipanas pada 1954. Keputusan Konferensi Alim Ulama yang kemudian dikukuhkan oleh Keputusan Muktamar NU ke-20 di Surabaya, 9-14 September 1954, memutuskan bahwa kedudukan Kepala Negara Republik Indonesia (Soekarno) dan alat-alat negara sebagai waliyul amridl dlaruri bisy syawkah (penguasa pemerintahan yang mengikat sebab kekuasaannya, atau pemegang pemerintahan de facto dengan kekuasaan penuh) (Masyhuri, 1997: 207-208). Keputusan ini dilakukan secara sadar untuk membentengi rongrongan pemberontak yang bermaksud menggantikan Pancasila sebagai dasar negara.

Dengan rangkaian nalar ijtihad politik keagamaan ini, "Deklarasi Hubungan Pancasila dan Islam" dirumuskan oleh kiai NU sebagai Keputusan Munas Alim Ulama NU tahun 1983 di Situbondo. Keputusan ini sebetulnya telah mengakhiri perdebatan paradigmatik tentang hubungan agama dan negara di Indonesia, sekaligus memperkuat basis teologis penerimaan NU atas kenyataan negara-bangsa (nation state) yang pluralistik dan demokratik. NU mendukung kenyataan ini sebagai ijtihad politik yang tepat.

KH Achmad Siddiq, tokoh intelektual di balik Deklarasi tersebut, mengemukakan bahwa Pancasila dan Islam sebagai dua kesatuan yang terpisah, namun tidak saling bertentangan: Pancasila adalah ideologi, sedangkan Islam adalah agama. Kiai Achmad lebih lanjut mengatakan:

"Dasar negara (Pancasila) dan agama Islam adalah dua hal yang dapat sejalan dan saling menunjang. Keduanya tidak bertentangan dan tidak boleh dipertentangkan. Keduanya tidak harus dipilih salah satu dengan sekaligus membuang yang lain.” (Feillard, 1999: 243)

Keputusan Musyawarah Nasional Alim Ulama Nahdlatul Ulama tahun 1983 menegaskan pemikiran politik keagamaan NU dalam merekonsiliasi Pancasila (sebagai ideologi dan dasar negara) dengan Islam (sebagai agama dan akidah). NU secara eksplisit menjelaskan dasar negara yang dimaksud, yakni Pancasila yang ber'Ketuhanan Yang Maha Esa' tanpa tambahan 'dengan kewajiban menjalankan syari'at Islam bagi pemeluk-pemeluknya'.

"Mengenai Pancasila, NU berpendapat bahwa sesungguhnya rumusan 
nilai-nilai yang dijadikan dasar negara Republik Indonesia sudah tuntas dengan ditetapkannya UUD 1945 pada tanggal 18 Agustus 1945. Semua pihak harus hanya memahami (memiliki persepsi tentang) dasar negara menurut bunyi dan maknanya yang terkandung dalam UUD 1945 (pembukaan, batang tubuh dan penjelasannya) itu (Nahdlatul Ulama, 1985: 57).

Bagi penulis, penerimaan total NU atas Pancasila sebagai satu-satunya asas dan menetapkan NKRI yang berdasarkan Pancasila dan UUD 1945 sebagai bentuk final menunjukkan bahwa ijtihad NU dalam konteks pencarian negara-bangsa dewasa ini telah titik. NU sudah tidak membutuhkan bentuk negara lain, meskipun menggunakan label Islam, Syari'ah, atau Islamiyyah.

Dalam pemahaman penulis atas nalar fikih politik NU, Negara Pancasila yang berketuhanan, berkemanusiaan, berkeadilan sosial, berkeadaban, bersatu, demokratis, dan bijaksana dalam melindungi seluruh warga Indonesia yang pluralistik adalah 'Negara Islam' itu sendiri. Inilah salah satu sumbangan terbesar yang monumental dalam seabad sejarah NU kepada bangsa Indonesia dan dunia Islam.

\section{Sikap Kebangsaan NU}

Konsekuensi dari penerimaan terhadap negara Indonesia yang berdasarkan Pancasila, dalam kebutuhan praktis dan strategis menumbuhkan sikap kebangsaan
Nahdlatul Ulama dari paham keagamaan yang selama ini digeluti, yakni sikap yang tercermin dari nilai-nilai Islam Ahlussunnah wal Jama'ah.

Di antara sikap ini dapat dijelaskan prtama Sikap Tawassuth dan I'tidal, yakni, suatu sikap tengah yang berintikan pada prinsip hidup yang menjunjung tinggi keharusan berlaku adil dan lurus di tengahtengah kehidupan bersama. Nahdlatul Ulama dengan sikap dasar ini seharusnya dapat menjadi kelompok panutan yang bersikap dan bertindak lurus dan selalu bersifat membangun serta menghindari segala bentuk pendekatan yang bersifat tatharruf (ekstrim).

Kedua Sikap Tasamuh, Yakni, sikap toleran dan menghargai terhadap perbedaan pandang, baik dalam masalah keagamaan, terutama hal-hal yang bersifat furu' atau menjadi masalah khilafiyyah serta dalam masalah kemasyarakatan dan kebudayaan.

Ketiga Sikap Tawazun, yakni, sikap seimbang dalam berkhidmah. Dalam hal ini adalah sikap menyerasikan khidmah kepada Allah SWT, khidmah kepada sesama manusia serta kepada lingkungan hidupnya, dan menyelaraskan kepentingan masa lalu, masa kini, dan masa mendatang.

Keempat Amar Ma'ruf dan Nahy Munkar yakni, sikap selalu memiliki kepekaan untuk mendorong perbuatan yang baik, berguna, dan bermanfaat bagi kehidupan bersama, serta menolak dan 
mencegah semua hal yang dapat menjerumuskan dan merendahkan nilai-nilai kehidupan (Nahdlatul Ulama, 1985: 15-16).

Implementasi sikap dasar kebangsaan ini dalam bidang politik-kekuasaan ditegaskan oleh Keputusan Muktamar NU ke-28 di Krapyak Yogyakarta bahwa NU sebagai suatu organisasi sosial-keagamaan (jam'iyyah diniyyah ijtima'iyyah) tidak mempunyai ikatan organisatoris dalam bentuk apapun dengan organisasi kekuatan sosial politik yang manapun juga. NU tidak akan menggabungkan diri secara organisatoris ke dalam organisasi sosial politik yang manapun, tetapi juga tidak akan bersikap menentang organisasi sosial politik yang manapun juga, dan tidak akan menjadi partai politik sendiri.

Dengan sikap politik seperti ini, NU diharapkan selalu terlibat dalam setiap upaya pengembangan budaya politik yang sehat dan bertanggungjawab agar dapat ikut serta menumbuhkan sikap hidup yang demokratis, konstitusional, serta membangun mekanisme musyawarah-mufakat dalam memecahkan masalah yang dihadapi bersama. Oleh karena itu, NU menetapkan prinsip-prinsip dasar etika politik bagi warganya sebagai berikut:

\section{Pertama Berpolitik bagi NU} mengandung arti keterlibatan warga negara dalam kehidupan berbangsa dan bernegara secara menyeluruh sesuai dengan Pancasila dan UUD 1945. Kedua Politik bagi NU adalah politik yang berwawasan kebangsaan dan menuju integrasi bangsa dengan langkah-langkah yang senantiasa menjunjung tinggi persatuan dan kesatuan untuk mencapai cita-cita bersama, yaitu terwujudnya masyarakat yang adil dan makmur lahir batin, dan dilakukan sebagai amal ibadah menuju kebahagiaan di dunia dan kehidupan di akherat. Ketiga Politik bagi NU adalah pengembangan nilai-nilai kemerdekaan yang hakiki dan demokratis, mendidik kedewasaan bangsa untuk menyadari hak, kewajiban, dan tanggungjawab untuk mencapai kemaslahatan bersama. Keempat Berpolitik bagi NU haruslah dilakukan dengan moral, etika, dan budaya yang ber-Ketuhanan Yang Maha Esa, berkemanusiaan yang adil dan beradab, menjunjung tinggi persatuan Indoensia, berkerakyatan yang dipimpin oleh hikmah kebijkasanaan dalam permusyawaratan/perwakilan, dan berkeadilan. Kelima Berpolitik bagi NU haruslah dilakukan dengan kejujuran nurani dan moral agama, konstitusional, adil, sesuai dengan peraturan dan norma-norma yang disepakati, serta dapat mengembangkan mekanisme musyawarah dalam memecahkan masalah bersama. Keenam Berpolitik bagi NU dilakukan untuk memperkokoh konsensus-konsesus nasional, dan dilakukan sesuai dengan akhlakul karimah sebagai pengamalan ajaran Islam Ahlussunnah wal Jamaa'ah. Ketujuh Berpolitik bagi NU, dengan dalih apapun, tidak boleh dilakukan 
dengan mengorbankan kepentingan bersama dan memecah belah persatuan. Kedelapan Perbedaan pandangan di antara aspiranaspiran politik warga NU harus tetap berjalan dalam suasana persaudaraan, tawadlu', dan saling menghargai satu sama lain, sehingga di dalam berpolitik itu tetap dijaga persatuan dan kesatuan di lingkungan NU. Sembilan Berpolitik bagi NU menuntut adanya komunikasi kemasyarakatan timbal balik dalam pembangunan nasional untuk menciptakan iklim yang memungkinkan perkembangan organisasi kemasyarakatan yang lebih mandiri dan mampu melaksanakan fungsinya sebagai sarana masyarakat untuk berserikat, menyalurkan aspirasi, serta berpartisipasi dalam pembangunan (Pusat Dokumetasi dan Informasi NU, 1992: 18-22).

\section{KESIMPULAN DAN SARAN}

Berkaitan dengan pemikiran politik NU "negara-Pancasila sama dengan negaraIslam," penulis ingin memberikan catatan bahwa kepolitikan yang diperankan NU seharusnya bukan politik yang berorientasi pada perebutan kekuasaan, melainkan politik untuk membumikan nilai-nilai dan ajaranajaran agama yang luhur dan mulia tentang kemanusiaan, keadilan, dan kesederajatan dalam kehidupan masyarakat.

Dengan meletakkan kunci masalah pada pengesahan hukum fikih, NU ternyata mampu melakukan proses penyesuaian dengan tuntutan negara modern sepanjang sejarah Indonesia merdeka. Tuntutan ini tidak saja menyentuh pada kebutuhan eksistensial belaka, tetapi juga pada aras substansial-paradigmatik bagi tatanan kehidupan bersama yang rukun, damai, demokratis, menghargai pluralitas, dan senantiasa bertumpu pada kerangka dasar keadilan sosial. Tawassuth, tawazun, ta'adul, dan tasamuch merupakan prinsip dasar bagi NU dalam menyelesiakan berbagai masalah kontemporer.

Negara-bangsa merupakan kenyataan sejarah yang tidak bisa dihindari oleh bangsa manapun, termasuk Indonesia. Selain karena tuntutan global, negara-bangsa merupakan konsep negara modern yang menjanjikan penyelesaian bagi tiap bangsa dalam menghadapi kenyataan kepusparagaman.

Nahdlatul Ulama sebagai organisasi sosial keagamaan terbesar di Indonesiayang dipimpin oleh para kiai tradisional pesantren--telah menawarkan suatu penyelesaian teologis yang cemerlang melalui fikih politik dalam hubungan Islam dan Pancasila. Penalaran fikih politik ini tampaknya dapat menjadi pedoman atau paling tidak inspirasi bagi organisasi keagamaan lain yang masih gamang menghadapi kenyataan 'negara-modern'. Sudahlah, Khilafah Islamiyyah adalah romantisme semu belaka. 
Keberhasilan NU dalam memberikan penyelesaian paradigmatik relasi agama dan negara ini mengindikasikan adanya pergeseran paradigma di kalangan NU sendiri dalam memandang kenyataan negarabangsa. Baik pada aspek siyasah, maupun aspek hukum dan peradaban, transformasi pemikiran di kalangan NU terus menggelinding secara dinamis hingga menyalip kalangan pembaru.

Tidak diingkari bahwa masyarakat NU adalah masyarakat fikih. Ini tidak lain

\section{DAFTAR PUSTAKA}

Aboebakar. (1957). Sedjarah Hidup KH.A. Wahid Hasjim dan Karangan Tersiar. Jakarta: Panitya Buku Peringatan.

AD/ART NU hasil keputusan Muktamar ke31 di Solo Tahun 2004.

al-Qayyim, A. I. (t.th). Achkam Ahlizd Zdimmah. Beirut: Darul Kutub alIlmiyyah.

Anam, C. (1985). Pertumbuhan dan Perkembangan Nahdlatul Ulama, Surabaya: Jatayu Sala.

Anam, C. (1985). Pertumbuhan dan Perkembangan Nahdlatul Ulama. Surabaya: Jatayu Sala.

Anderson, B. R. (1977). Religion and Politics in Indonesia Since Independence. in Benedict R. O'G Anderson, Mitsuo Nakamura and Muhammad Slamet (edd), Religion and Social Ethos in Indonesia. Clayton: Centre of Southeast Asian Studies, Monash University.

Anshari, E. S. (1997). Piagam Jakarta 22 Juni 1945, Sebuah Konsensus Nasional tentang Dasar Negara Republik Indonesia (1945-1949). Jakarta: Gema Insani Press. karena NU berbasis pesantren, dan pesantren identik dengan paradigma fikih. Dengan kata lain, NU adalah pesantren-makro, dan pesantren adalah NU-mikro. Akan tetapi mempertimbangkan kenyataan pemikiran di atas, penulis kira tidak berlebihan jika dicatat bahwa di dalam kalangan NU tengah terjadi perubahan paradigma fikih yang sangat transformatif dari literalisme ke kontekstualisme, dari skripturalisme ke substansialisme, dan dari madzhab qouli ke madzhab manhaji.

Azra, A. (2006). Islamic radical movements in Indonesia. The Jakarta Post.com, Outlook 2006. http://old.thejakartapost.com/Outlook20 06/pol05b.asp .

az-Zuhaili, W. (t.th). Atsarul Charb fil Fiqhil Islâmy. Syria: Darul Fikr.

Basalim, S. E. Y., \& Umar. (2000). Reformasi Konstitusi Indonesia, Perubahan Pertama UUD 1945. Jakarta: Pustaka Indonesia Satu.

Basalim, U. (2002). Pro-Kontra Piagam Jakarta di Era Reformasi. Jakarta: Pustaka Indonesia Satu.

Brackman, A. C. (1963). Indonesian Communism: A History. New York: Frederrick A. Praeger.

Bruinessen, M. V. (1999). NU: Tradisi, Relasi-relasi Kuasa, Pencarian Wacana Baru. Yogyakarta: LkiS.Bush, R. (2009). Nahdlatul Ulama and the Struggle for Power within Islam and Politics in Indonesia. Singapore: Iseas.

Fealy, G. (2003). Ijtihad Politik Ulama: Sejarah NU 1952-1967. Yogyakarta: LkiS.

Feillard, A. (1999). NU vis-à-vis Negara, Pencarian Isi, Bentuk dan Makna. Yogyakarta: LkiS. 
Haidar, M. A. (1994). Nahdatul Ulama dan Islam di Indonesia, Pendekatan Fikih dalam Politik. Jakarta: Gramedia.

Halim, KH. A. (1970). Sejarah Perjuangan Kyai Haji Abdul Wahab. Bandung: Penerbit Baru.

Harun, L. (1986). Muhammadiyyah dan Asas Pancasila Jakarta: Pustaka Panjimas.

Hosen, N. (2007). Shari'a \& Constitutional Reform in Indonesia. Singapore: Iseas.

http://www.fpi.or.id/default.asp

http://www.kpu.go.id/

http://www.mpr.go.id/pimpinan1/?p=337, diakses 20 September 2008.

Keputusan Muktamar NU 1936 di Banjarmasin, Ahkam al-Fuqaha, jilid 3, Semarang: Menara Kudus, 1980.

Keputusan Musyawarah Nasional Alim Ulama Nahdlatul Ulama Nomor II/Munu/1404/1983 tentang Pemulihan Khittah Nahdlatul Ulama 1926, tanggal 21 Desember 1983.

Khitthah Nahdlatul Ulama, Jakarta: Lajnah Ta'lif wan Nasyar, 1985.

KOMPAS, 7 April 2002.

Lindsey, T. (2002). Indonesian Constitutional Reform: Muddling Towards Democracy. Singapore Journal of International \& Comparative Law, 6.

Ma'arif, A. S. (1985). Islam dan Masalah Kenegaraan: Studi tentang Percaturan dalam Konstituante. Jakarta: LP3ES.

Masyhuri, K. H. A. A. (1997). Masalah Keagamaan Hasil Muktamar dan Munas Ulama Nahdlatul Ulama Kesatu-1926 s/d Kedua Puluh Sembilan 1994. Surabaya: Kerjasama PP RMI dengan Dinamika Press.

Mumtaz, A., (ed.). (1986). State, Politics and Islam. Washington: American Trust Publication.

Nasution, A. B. (1992). The Aspiration for Constitutional Government in Indonesia: A Sosio-Legal Study of the Indonesian Konstituante 1956-1959.
Rais, M. A. (2002). Islam dan Negara di Indonesia: Mencari Akhir Pencarian. Kata Pengantar buku Umar Basalim, Pro-Kontra Piagam Jakarta di Era Reformasi. Jakarta: Pustaka Indonesia Satu.

SK Muktamar XXX NU Nomor: 003/MNU30/11/1999.

Zuhri, S. (1983). Kyai Haji Abdul Wahab Khasbullah: Bapak dan Pendiri Nahdlatul Ulama. Yogyakarta: Pustaka Falakiyah. 